\title{
SOME ASPECTS OF BIOLOGY OF THE BAR-EYED GOBY GLOSSOGOBIUS GIURIS (HAMILTON 1822) (PERCIFORMES: GOBIIDAE) FROM NETRAKONA
}

\author{
BIMAL KANTA SAHA ${ }^{1}$, MD. FUAD HASSAN ${ }^{2}$ AND APARNA SAHA \\ Fisheries Lab, Department of Zoology, Netrakona Govt. College, Netrakona-2400, Bangladesh \\ ${ }^{2}$ Department of Agricultural Statistics, Bangladesh Agricultural University, \\ Mymensingh-2202, Bangladesh
}

\begin{abstract}
The investigation was conducted on some aspects of biology viz. morphometrics, meristics, length-weight relationship and coefficient of condition of the Bar-eyed goby Glossogobius giuris. The mean of total length (TL) (94.42 $\pm 18.52 \mathrm{~mm})$, standard length (SL) $(73.13 \pm 3.45 \mathrm{~mm})$, pre-dorsal length (PDL) $(28.8 \pm 7.32 \mathrm{~mm})$, head length (HL) $(23.9 \pm 4.87 \mathrm{~mm})$, snout length $(\mathrm{SnL})(8.15 \pm 1.9 \mathrm{~mm})$ and height of body (HB) $(14.17 \pm$ $3.29 \mathrm{~mm}$ ) were determined.The relationships between the total length and other body parameters were found to be positively correlated and highly significant. The fin formula is $\mathrm{D}_{1} .6 ; \mathrm{D}_{2} .1 / 9-10 ; \mathrm{P}_{1} .17-21 ; \mathrm{P}_{2} .1 / 5 ; \mathrm{A} .1 / 9 ; \mathrm{C} .17$. The length-weight relationships of combined sex of $G$. giuris were determined as Log TW $=-4.802+2.857$ Log TL. The coefficient of conditions from the $k o$ of combined sex and from the $k c$ of combined sex was determined as $0.834 \pm 0.132$ and $0.827 \pm 0.027$, respectively. $K n$ values of combined sex were found to be $1.001 \pm 0.156$.
\end{abstract}

Key words: Bele, Glossogobius giuris, Morphometrics, Length-weight relationship, Coefficient of correlation

\section{Introduction}

The gobies (Family Gobiidae), a very prominent element in the fish fauna of Bangladesh, is a diversified group occurring in temperate and tropical zones throughout the world.They are mostly small, carnivorous, bottom-dwellers living along the shores of the bay, estuaries and river mouths and also in streams, lakes and swamps.The commonest of all the gobies in Bangladesh is the Bar-eyed goby, Glossogobius giuris (Hamilton 1822), locally known as Bele or Bailla. Bele occurs in esturine and freshwaters throughout Bangladesh (Rahman 1989). The species is distributed to East Coast of Africa, India, Pakistan, Ceylon, Burma, the Phillipines, China, Japan and New Caledonia (Srivastava 1968). G. giuris is somewhat hardy, but it can not survive in muddy water for long. The species is a good sport on rod and line with a bait of small prawn. Bele is highly esteemed as food and one of the varieties found in both freshwater and brackish water, largely caught and eaten (Bhuiyan 1964). 
The morphometric and meristic characters of fishes and their relationships are used in taxonomy to prepare keys for identification in the fishery science. They are also helpful in differentiating stocks or subspecies. The morphometry of many fishes have been determined in India and used in taxonomy (Ganguly et al.1959, Prakash and Verma 1982, Tandon et al. 1993, Chunder 1997 and Mehta and Bapat 1977). Some works on the morphometry of some fishes have also been published in Bangladesh (Shafi and Quddus 1974, 1975, Azadi et al. 1992, Azadi and Naser 1996, Azadi et al. 1999 and Saha and Saha 2010, 2011).

The purpose of the length-weight analysis is to describe mathematical relationship between length and weight, primarily so that one may be converted into other and of condition factors to measure the variation from the expected weight for length of individual fish or groups of fishes as indication of relative robustness, plumpness or fatness, degree of well-being etc. (Le Cren 1951). Determination of ponderal index helps in the conversion of length into weight and vice versa (Doha 1970). Works on lengthweight relationship and condition factor of freshwater small fishes have been done by Saha and Saha (2010, 2011).

Breeding of G. giuris has been studied (Le Cren 1951, Bhowmick 1965, Doha 1974, Haque 1983 and Saha \& Saha 2009). But no study has been conducted on morphometrics, meristics, length-weight relationship and condition factors of G. giuris from Bangladesh.This type of study may have practical value in culture, management and further development of fishery relating to this fish species in Bangladesh.

Therefore, an investigation was conducted to determine some aspects of biology viz. morphometrics, meristics, length-weight relationship and coefficient of condition of the Bar-eyed goby G. giuris from Netrakona during the tenure from February 2004 to January 2005.

\section{Materials and Methods}

The samples of Bele for the present work were collected once a month from February 2004 to January 2005 from the fishermen of three fish markets of Netrakona district town. A total number of 299 individuals of Bele was collected for the study period. After collection, the fishes were preserved in $10 \%$ formalin.The samples were labelled monthwise in plastic jar and kept in the fisheries Laboratory. Different lengths of fishes were measured in the nearest mm by means of a measuring board fitted with a centimeter scale and the weights were recorded by means of a sensitive Pan balance (TG 928A, capacity 200g, China) in g. For fin formula, Rahman (1989) was followed. 
Size frequency distribution: The size frequency distribution was calculated for each length group of $11.0 \mathrm{~mm}$ class interval by Peterson Polygon method. Statistical formulae were used to establish mathematical relationship between the total length and other lengths (Snedecor 1956 and Simpson et al.1960). The total length (TL) and total eight (TW) relationship of these fishes were determined by using the logarithmic transformation of the formula: $\mathrm{W}=\mathrm{aL}$ (Le Cren 1951), where $\mathrm{W}=$ weight, $\mathrm{L}=$ length, a is a constant and an xponent. Values for a and $\mathrm{n}$ were found empirically.The value of the coefficient of condition $(\mathrm{k})$ was calculated from the cube law equation $\mathrm{W}=\mathrm{KTL}^{3} \times 10^{5}$ or $K=\frac{T W \times 10^{5}}{T L^{3}}$, where $\mathrm{TW}=$ total weight, $\mathrm{TL}=$ total length, and $\mathrm{K}=$ the factor of proportion.

\section{Results and Discussion}

\section{Morphometrics}

Size frequency distribution: The data on size frequency distribution of 306 individuals of males and females of Bele are presented in Fig. 1. The specimens were grouped into 12 size groups of $11.0 \mathrm{~mm}$ class intervals. Minimum number of male was found in one size group 125-136 mm while no male was found in five size groups viz. 136-147 mm, 147$158 \mathrm{~mm}, 158-169 \mathrm{~mm}, 169-180 \mathrm{~mm}$ and $180-191 \mathrm{~mm}$. Maximum number of male was recorded in one size group (92-103 $\mathrm{mm}$ ). On the other hand, minimum number of female was found in two size groups (136-147 mm and 180-191 mm) while maximum number of female was observed in 92-103 mm size group. Females were absent from three size groups (147-158 mm, 158-169 mm and 169-180 mm). According to Saha and Saha (2011), minimum number of male (132-138 $\mathrm{mm}$ and 138-144 mm size group) and female (150-156 mm and 156-162 mm size group) of Nandus nandus occurs in 2 size groups. Saha and Saha (2011) also reported that the highest number of male and female was available in $96-102 \mathrm{~mm}$ and 102-108 mm size groups, respectively in beel water of Netrakona.

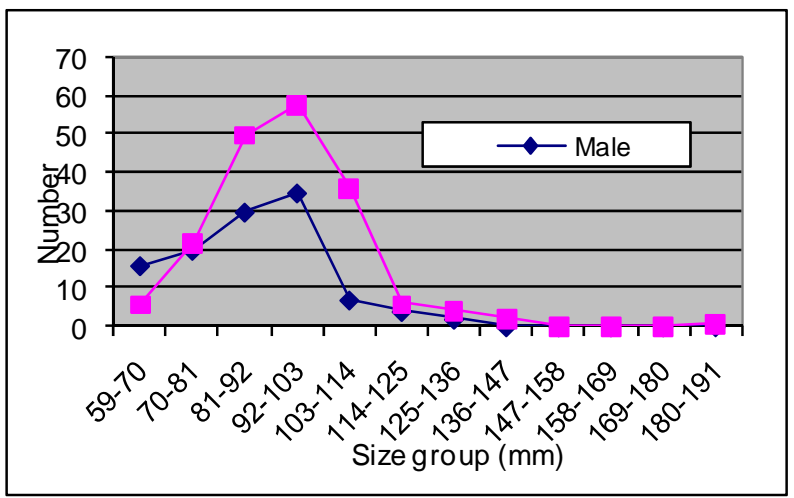

Fig.1. Size frequency distribution of male and female of Bele, Glossogobius giuris sampled from Netrakona. 
Estimation of lengths: The total length (TL) of male individuals of G. giuris attained the range from $59 \mathrm{~mm}$ to $135 \mathrm{~mm}$ with the mean of $89.14 \pm 14.77 \mathrm{~mm}$. In females, it varied from $63 \mathrm{~mm}$ to $190 \mathrm{~mm}$ with an average of $97.67 \pm 19.8 \mathrm{~mm}$ and in combined sex, the average being $94.42 \pm 18.52 \mathrm{~mm}$. Information on maximum total length of $G$. giuris are achieved from different workers viz. $350 \mathrm{~mm}$ (Munro 1955), $170 \mathrm{~mm}$ (Bhuiyan 1964), 108-152 mm (Srivastava 1968), 450 mm (Day 1878) and 292 mm (Rahman 1989) from home and abroad.

The standard length (SL) of males attained the variation from $46 \mathrm{~mm}$ to $107 \mathrm{~mm}$ with the mean of $70.1 \pm 12.03 \mathrm{~mm}$. In females, it ranged from $50 \mathrm{~mm}$ to $152 \mathrm{~mm}$ with an average of $75.03 \pm 13.92 \mathrm{~mm}$ and in combined sex, the mean being $73.13 \pm 13.45 \mathrm{~mm}$.

The head length (HL) of male G. giuris ranged from $14 \mathrm{~mm}$ to $35 \mathrm{~mm}$ with the mean of $22.67 \pm 4.47 \mathrm{~mm}$. In females, it varied from $15 \mathrm{~mm}$ to $50 \mathrm{~mm}$ with the mean of $24.68 \pm$ $4.95 \mathrm{~mm}$ and in combined sex, the mean calculated to be $23.9 \pm 4.87 \mathrm{~mm}$.

The pre-dorsal length (PDL) of males showed a range from $19 \mathrm{~mm}$ to $38 \mathrm{~mm}$ with the average of $27.12 \pm 5.07 \mathrm{~mm}$. In females, it varied from $19 \mathrm{~mm}$ to $61 \mathrm{~mm}$ with the mean calculated $29.8 \pm 8.23 \mathrm{~mm}$ and in combined sex, the average being $28.8 \pm 7.32 \mathrm{~mm}$.

The snout length $(\mathrm{SnL})$ of males ranged from $2.5 \mathrm{~mm}$ to $13 \mathrm{~mm}$ with the mean of $7.71 \pm$ $1.83 \mathrm{~mm}$. In females, it varied from $05 \mathrm{~mm}$ to $15 \mathrm{~mm}$ with the mean of $8.42 \pm 1.9 \mathrm{~mm}$ and in combined sex, the mean calculated to be $8.15 \pm 1.9 \mathrm{~mm}$.

The height of body (HB) of males was found to range from $08 \mathrm{~mm}$ to $22 \mathrm{~mm}$ with the mean of $13.18 \pm 2.97 \mathrm{~mm}$. In females, it varied from $09 \mathrm{~mm}$ to $34 \mathrm{~mm}$ with an average of $14.74 \pm 3.34 \mathrm{~mm}$ and in combined sex, the average calculated to be $14.17 \pm 3.29 \mathrm{~mm}$.

The total weight (TW) of male individuals of G. giuris was found to be $01.6 \mathrm{~g}$ to $23 \mathrm{~g}$ with the mean of $6.48 \pm 3.58 \mathrm{~g}$. In females, it varied from $1.8 \mathrm{~g}$ to $55.8 \mathrm{~g}$ with an average of $9.62 \pm 8.91 \mathrm{~g}$ and in combined sex, the mean being $8.48 \pm 7.56 \mathrm{~g}$.

Total length (TL) and standard length (SL): Scattered diagram (Fig. 2) of total length and standard length of Bele (G. giuris) exhibits a positive and linear relationship between them. The coefficient of correlation is highly significant $(r=0.90)$. Saha and Saha (2011) determined the coefficient of correlation $(r=0.982)$ of Nandus nandus between total length and standard length which closely correlates with the present report.The relationships between the total length (TL) and standard length (SL) can be expressed by the following relations: 
$\log \mathrm{SL}=-592+0.7877 \log \mathrm{TL}$

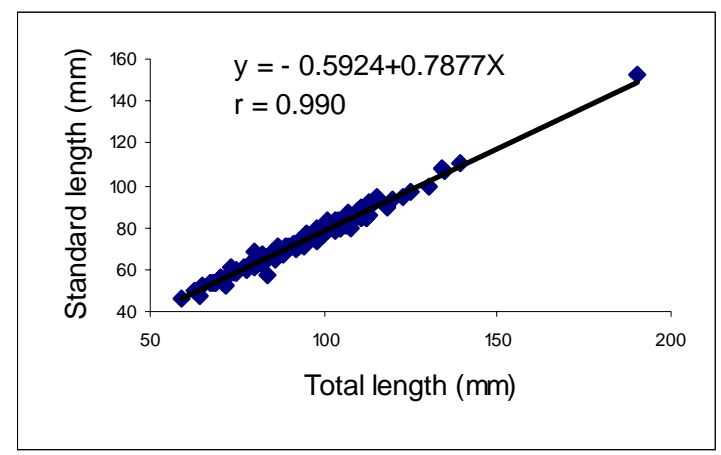

Fig. 2. Relationship between total length and standard length of Bele, Glossogobius giuris.

Total length (TL) and head length (HL): The relationships between total length and head length of Bele are linear, positive and highly significant $(r=0.962)$ between them. The coefficient of correlation ( $r=0.962$ ) between total length and head length of Bele shows maximum similarity with the finding $(r=0.951)$ of Saha and Saha (2011) who worked on Nandus nandus from Netrakona.The relationships between the total length (TL) and head length (HL) can be expressed by the following relations (Fig. 3):

$\log H L=-2.0318+0.2772 \log \mathrm{TL}$

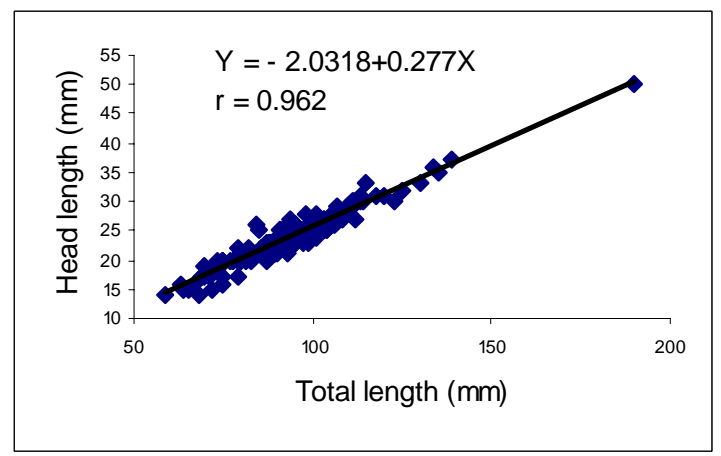

Fig.3. Relationship between total length and head length of Bele, Glossogobius giuris.

Total length (TL) and snout length (SNL): Scattered diagram (Fig. 4) of total length and snout length hints a positive and linear relationship between them. The coefficient of correlation was $\mathrm{r}=0.882$, which was strong and highly significant.The coefficient of correlation $(r=0.891)$ recorded by Saha and Saha (2011) closely coincides with this finding. The relationships between total length (TL) and snout length $(\mathrm{SnL})$ were expressed by the following relations: 
$\log \operatorname{SnL}=-4.4497+0.1297 \log \mathrm{TL}$

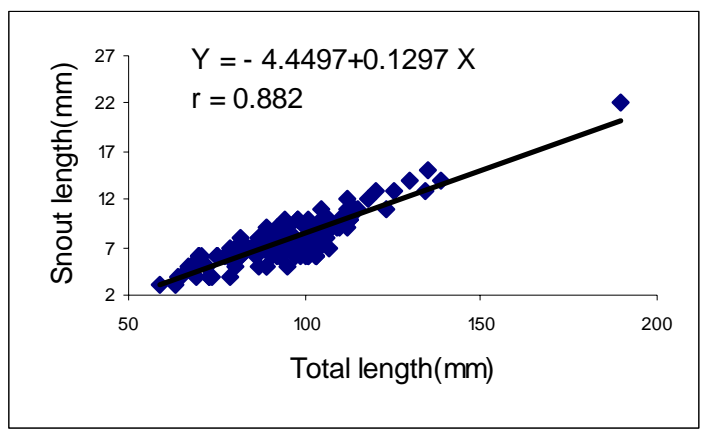

Fig.4. Relationship between total length and snout length of Bele, Glossogobius giuris.

Total length (TL) and pre-dorsal length (PDL): Scattered diagram of total length and predorsal length of Bele (G. giuris) exhibits a positive and linear relationship between them (Fig. 5). The coefficient of correlation is highly significant $(r=0.90)$. The coefficient of correlation ( $r=0.888)$ of Nandus nandus by Saha and Saha (2011) showed resemblance with the present study. The relationships between the total length (TL) and pre-dorsal length (PDL) were expressed by the following relations:

$\log$ PDL $=1.8462+0.3233 \log \mathrm{TL}$

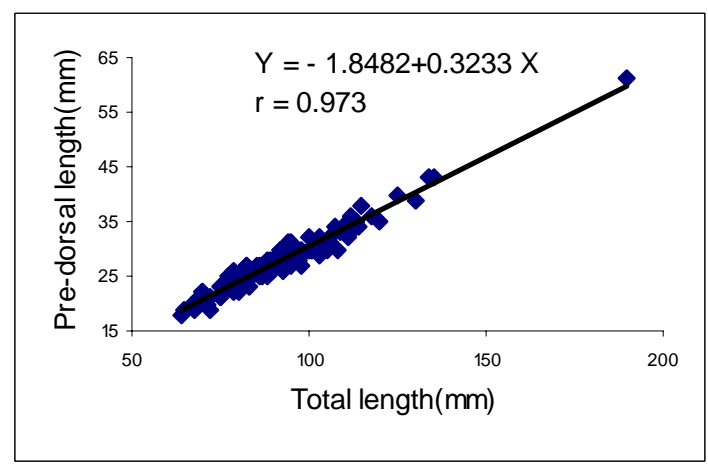

Fig. 5. Relationship between total length and pre-dorsal length of Bele, Glossogobius giuris.

Total length (TL) and height of body (HB): The relationships between total length and height of body of Bele are linear, positive and highly significant (Fig. 6). The correlation coefficient is 0.924. The coefficient of correlation $(\mathrm{r}=0.839)$ of Nandus nandus (Saha and Saha 2011) is in conformity with this observation.The relationships between the total length (TL) and height of body (HB) were expressed by the following relations: 
$\log \mathrm{HB}=-4.4205+0.1997 \log \mathrm{TL}$

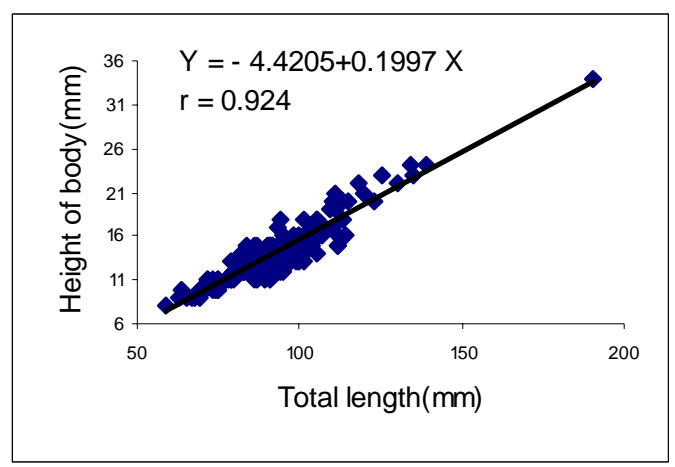

Fig.6. Relationship between total length and height of body of Bele, Glossogobius giuris.

Meristics: The lateral line of Glossogobius giuris is complete. Ist dorsal fin with 6 unbranched rays; $2^{\text {nd }}$ dorsal fin with 1 unbranched and 9-10 branched rays; Pectoral fin with 17-21 branched rays; Pelvic fin with 1 unbranched and 5 branched rays; Anal fin with 1 unbranched and 9 branched rays; Caudal fin with 17 branched rays of Glossogobius giuris were determined. According to Rahman (1989), the fin formula is $\mathrm{D}_{1} .6$; $\mathrm{D}_{2} .1 / 8-9$; $\mathrm{P}_{1} .18-20 ; \mathrm{P}_{2} .6$ (1/5); A.1/8-9. Bhuiyan (1964) showed the fin formula of G. giuris as B.iv; $\mathrm{D}_{1} .6 ; \mathrm{D}_{2} .9-10$; A.9-10; V.6; C.17; L.l.32-34; L.tr.8/9 from Dacca.

The fin formula of Bele (G.giuris) from Netrakona stands as follows: $\mathrm{D}_{1}$. 6; $\mathrm{D}_{2}$. 1/9-10; $\mathrm{P}_{1} .17-21 ; \mathrm{P}_{2} .1 / 5$; A.1/9; C.17.

Length-weight relationship: The length-weight relationships for 306 individuals of Bele, Glossogobius giuris ranging in size from $59.0 \mathrm{~mm}$ to $190.0 \mathrm{~mm}$ and in total weight from $1.6 \mathrm{~g}$ to $55.8 \mathrm{~g}$ throughout the study period were determined. The length-weight relationships of male, female and combined sex were determined as $\log \mathrm{TW}=-4.704+$ 2.811Log TL, Log TW = -4.910 + 2.909 Log TL and Log TW = -4.802 + 2.857 Log TL, respectively (Figs. 7-9). It is evident from Figs. 7- 9 that the weights bear a curvilinear relationship with the total length. Doha (1974) determined the equation from lengthweight relationship of G. giuris as Log W= $-4.657+2.816 \log \mathrm{L}$ from Mymensingh water which is in conformity with this study. Saha and Saha (2011) calculated the equations from the length-weight relationship of the freshwater percid fish, Nandus nandus as Log $\mathrm{W}=5.274+3.23 \log \mathrm{L}$ in male, $\log \mathrm{W}=4.538+2.89 \log \mathrm{L}$ in female and $\log \mathrm{W}=$ 4.751+2.39 Log L in combined sex from Netrakona. 


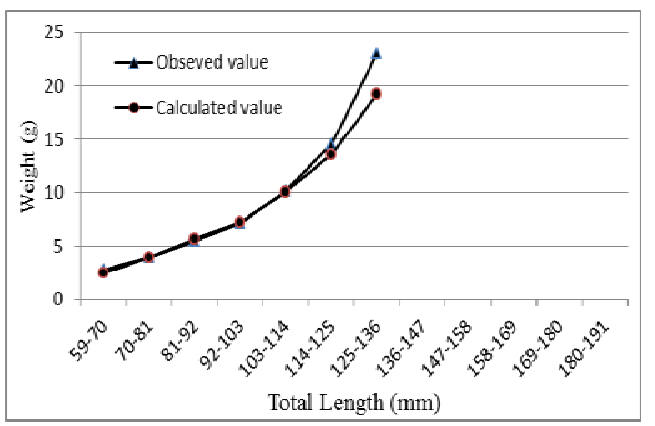

Fig.7. Relationship between total length and total weight in male Glossogobius giuris.

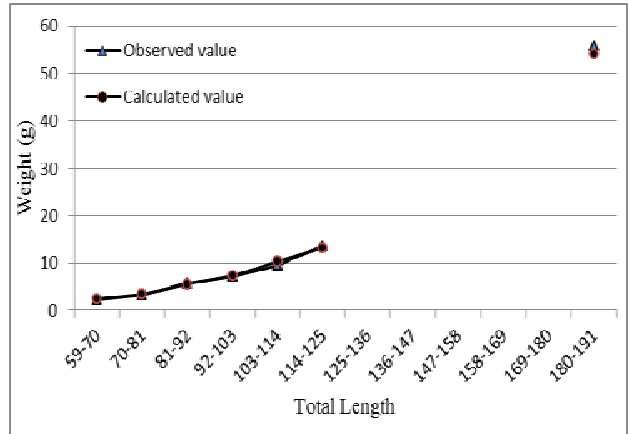

Fig.8. Relationship between total length and total weight in female Glossogobius giuris.

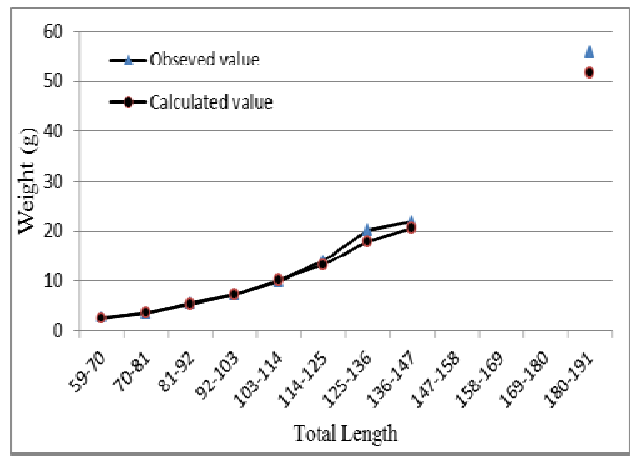

Fig.9. Relationship between total length and total weight in combined sex of Glossogobius giuris.

Coefficient of condition from the observed value (ko): The coefficient of condition from the observed value of Glossogobius giuris of male was found to range from 0.79060.8489 with an average of 0.8206 ; in case of female, it was $0.8274-0.9740$ with the mean of 0.8697 and in combined sex, the mean and the range were 0.8564 and $0.8165-0.9042$, respectively (Figs. 10, 11 and 12). Doha (1974) estimated the condition factor $(K)$ of 
Glossogobius giuris as $0.784-1.338$ with the mean of 0.9991 which is in conformity with the present finding.

Coefficient of condition from the calculated value ( $k c)$ : The coefficient of condition from the calculated value of Glossogobius giuris of male was estimated as 0.7522-0.8891 with the mean of 0.8564; in case of female, it varied from 0.8060-0.9234 with the mean of 0.8689 and in combined sex, it was found to range from 0.8411-0.8682 with an average of 0.8558 (Figs. 10-12).

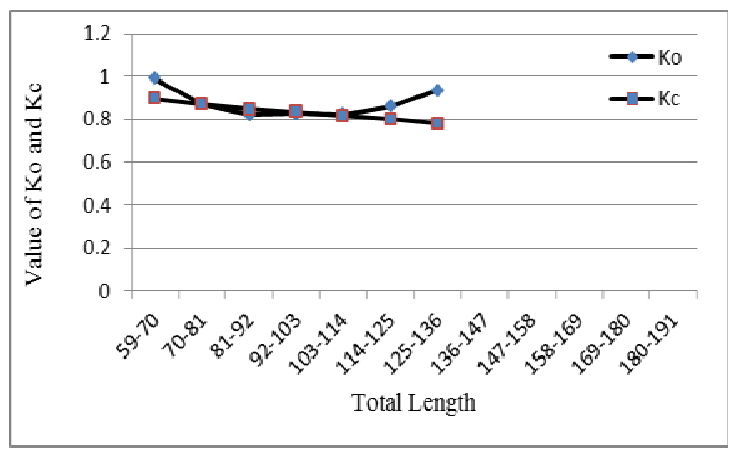

Fig. 10. Relationship between total length (TL) and coefficient of condition for observed weight $(K o)$ and calculated weight $(K c)$ in male $G$. giuris.

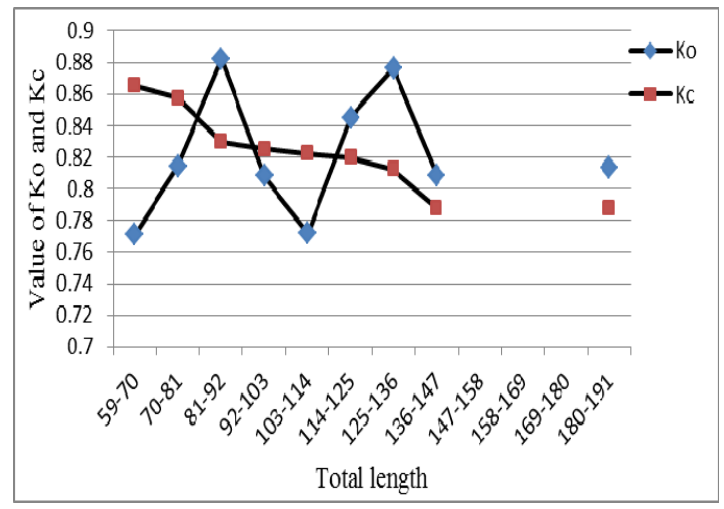

Fig.11. Relationship between total length (TL) and coefficient of condition for observed weight $(K o)$ and calculated weight $(K c)$ in female $G$. giuris. 


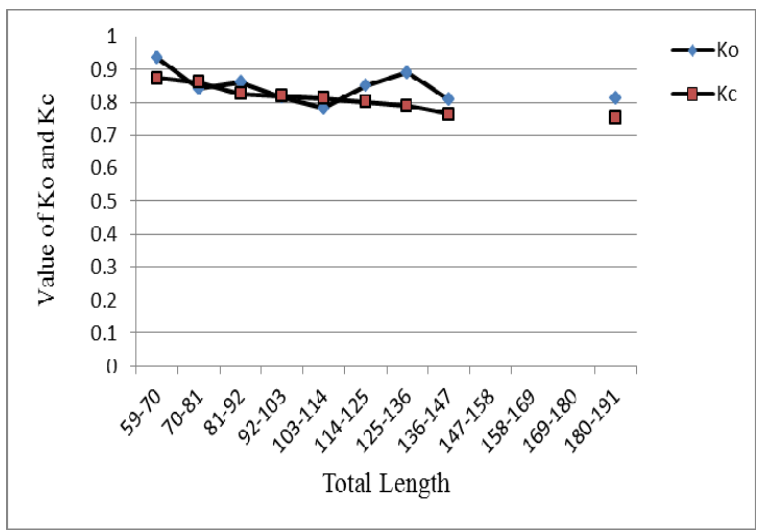

Fig.12. Relationship between total length (TL) and coefficient of condition for observed weight $(K o)$ and calculated weight $(K c)$ in combined sex of G. giuris.

Relative coefficient of condition (Kn): The relative coefficient of condition $(\mathrm{Kn})$ of Glossogobius giuris of male was found to be 0.9402-1.1071 with the mean of 1.0006; in case of female, it ranged from 0.919-1.125 with the mean of 1.0035; in combined sex, the range was 0.960-1.057 with an average of 1.0002 (Fig. 13). Doha (1974) determined the mean of Kn of G. giuris as 0.9993 with a range of 0.903-1.117 which shows similarity with the present work. However, the $K n$ values shows dispersion in all the sex groups of freshwater fishes (Rahman 1990 and Saha \& Saha 2010, 2011) which is in agreement with the present study.

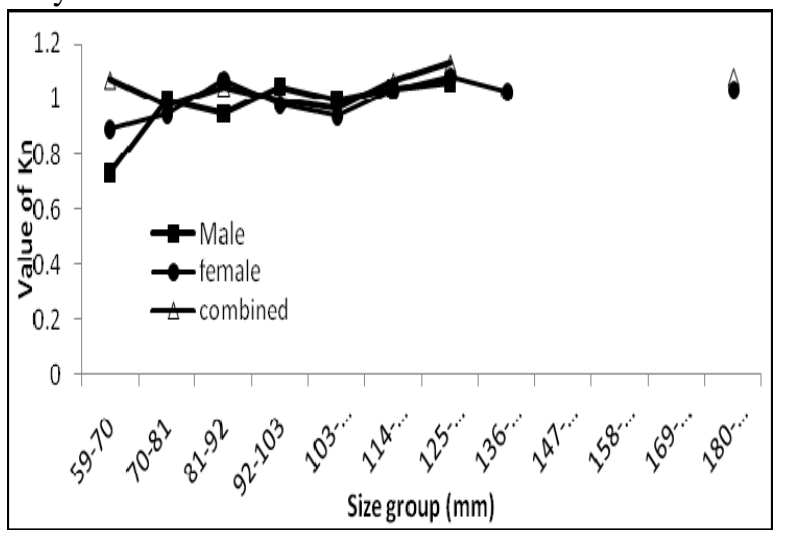

Fig.13. Relationship between total length and relative coefficient condition $(K n)$ for male, female and combined sex of $G$. giuris. 


\section{Acknowledgement}

The authors wish to record their deep sense of gratitude and appreciation to Professor Md. Ruhul Amin, Principal, Netrakona Govt. College, Netrakona, Bangladesh for providing necessary facilities in the department of Zoology during the course of the research work.

\section{References}

Azadi, M.A., M.A. Islam and J.G. Paul. 1992. Biology and fishery of the Catfish, Mystus aor in the Kaptai reservoir, Bangladesh. In: Reservoir Fisheries of Asia (Ed. De Silva,S.S.) IDRC, Ottawa, Ont. Canada, pp. 125-140.

Azadi, M.A. and A. Naser. 1996. Morphometry of Labeo bata (Hamilton) from Kaptai reservoir, Bangladesh. Chittagong Univ. Stud. Part 11 Sci. Vol. 20: 133-134.

Azadi, M.A., M.A. Islam and M.A. Masud. 1999. Morphometry of Jew fish, Johnius coitor from the Karnafuli River and its estuary. Bangladesh J.Zool. 23(2):191- 194.

Bhowmick, R.M.1965. Studies on some aspects of the biology of Glossogobius giuris (Hamilton) with notes on its fishery in the Hoogly estuary. Proc. Indo- Pacific Fish. Con. 11: 99115.

Bhuiyan, A.L. 1964. Fishes of Dacca. Asiatic Society of Pakistan. 148pp.

Chunder, S.L.1997. Morphometry characters and their relationship in Gudusia chapra (Ham.). Proc. Ind. Acad. Sci. 80B: 57-62.

Day, F. 1878. The Fishes of India: being a Natural History of the Fishes known to inhabit the seas and Freshwaters of India, Burma and Ceylon. Reproduced in 1958 by Williamson Dowson and Sons, London, $778 \mathrm{pp}$.

Doha, S. 1970. Length-weight relationship and condition in the male and female shrimp, Palaemon malcolmsoni (Palaemonidae, Decapoda, Crustacea). Pak. J. Zool. 2(2):185-193.

Doha, S. 1974. Investigation into the biology of Goby, Glossogobius giuris (Hamilton- Buchanan) (Perciformes:Gobiidae). Bangladesh J. Zool. 2(2): 95-105.

Ganguly, D.N., B. Mitra and N. Bhattacharya. 1959. On the inter-relationship between total length, standard length, depth and weight of Lates calcarifer. Proc. Nat. Inst. Sci. India 25B: 174-187.

Haque, S. 1983. Some aspects of biology of the Freshwater goby, Glossogobius giuris (HamiltonBuchanan) (Gobiidae:Perciformes) from the river Padma. M.Sc.Thesis, Rajshahi University, Rajshahi, 135 pp.

Le Cren, E.D. 1951.The length-weight relationship and seasonal cycle in gonad weight and condition in the perch (Perca fluviatilis). J. Anim. Ecol.20:201-219.

Mehta, D.P. and S.S. Bapat. 1977. Stastical relationship between body measurements of Ophiocephalus gachua (Ham- Buch). Mathwada Univ. J. Sci. 16:74-78.

Munro, I.S.R. 1955. Marine and Freshwater fishes of Ceylon. Department of External Affairs, Canberra publication. 1-XV, 134 pp. 55 plates.

Prakash, M. and B.R.Verma. 1982. Morphometric characters and their relationship in Notopterus notopterus (Pallas). Bangladesh J. Zool. 10: 14-21.

Rahman, A.K.A.1989. Freshwater fishes of Bangladesh. Published by the Zoological Society of Bangladesh, University of Dhaka, Dhaka, Bangladesh. 364 pp.

Rahman, M. H.1990. Studies on some aspects of biology of Lepidocephalus guntea (Hamilton) (Cypriniformes:Cobitidae). M.Sc. Thesis, Department of Zoology, Rajshahi University. Rajshahi. 128pp.

Srivastava, G. J. 1968. Fishes of Eastern Uttar Pradesh. Vishwavidyalaya Prakashan, Varanasi. India. 163 pp. 
Simpson, G.G., A. Roe and R.C.Lewontin. 1960. Quantitative Zoology. Harcourt Brace \& Co. New York, 440 pp.

Snedecor, G.W. 1965. Statistical methods. Lowa State University Press, Amer. Lowa, 53 pp.

Saha, B. K. and A. Saha. 2009. Some aspects of the reproductive biology of Glossogobius giuris (Hamilton) from Netrakon. The Journal of NOAMI. 26(1): 71-81.

Saha B.K. and A. Saha. 2010. Some aspects of biology of Chola punti Puntius chola (Hamilton) from the Kangsa River. Bangladesh J. Sci. Ind. Res. 45(4): 309- 314.

Saha, B.K. and A. Saha. 2011. Morphometrics, length-weight relationship, condition factor and sex ratio of Nandus nandus (Hamilton-Buchanan) from beel waters. Bangladesh J. Zool. 39(1): 77-78.

Shafi M. and M.M.A. Quddus. 1974. The length-weight relationship and conditions in the carp, Catla catla (Hamilton-Buchanan 1882). J. Asiat. Soc. Bangladesh. 19(2):71- 80.

Shafi, M. and M.M.A. Quddus. 1975. The length- weight and length- girth relationships and condition in the Carp, Labeo rohita (Hamilton, 1822). Bangladesh J. Sci. Ind. Res. 10 (3\&4): 268-273.

Tandon, K.K., M.S. Johal and S. Bala. 1993. Morphometry of Cirrhinus reba (Hamilton) from Kanjli wetland, Punjab, India. Res. Bull. Punjab Univ. 43: 73-79.

(Revised copy received on 11-04-2016) 